\title{
The Waste Solutions Forum: An Innovative and Cooperative Approach to Support the Agricultural Community and Protect Water Quality
}

\author{
Eric Bendfeldt, Katharine Knowlton, Tanya Denckla Cobb, Franklin \\ Dukes, Kathy Holm, and Jactone Arogo Ogejo
}

\begin{abstract}
Nitrogen $(N)$ and phosphorus $(P)$ contamination of water resources is a significant concern for the Chesapeake Bay and threatens the economic viability of farming communities within the Shenandoah Valley. Nutrient reduction challenges in the Shenandoah Valley are greater because the excess nutrients in the region are largely in the form of manure and poultry litter, which have traditionally been applied to cropland and are difficult and expensive to transport long distances. Poultry is Virginia's top revenue earner for receipts in the agricultural sector and employs 12,000 people statewide. Dairy farming generates about $\$ 300$ million in farm receipts in Virginia and 40 percent of the state's 795 dairy farms are located in the Shenandoah Valley. The Waste Solutions Forum was convened in April 2005 by Virginia Tech faculty and a planning committee comprised of individuals representing the agricultural and environment conservation communities and other interest groups to explore innovative, economically viable, and long-term solutions to these nutrient challenges and issues. Nearly 80 invitees from the agricultural, business, regulatory, environmental, and academic communities participated in a facilitated "outcome-based" discussion that resulted in a detailed strategy for addressing excess manure and litter, including specific priority actions for research, pilot projects, policy, and education. The Forum and its steering committee continue to focus on these strategies and long-term solutions to the nutrient challenge facing animal agriculture in an effort to support the agricultural community and protect water quality. This collaborative approach of traditional and non-traditional partnerships has allowed the Forum to make significant progress toward long-term solutions and achieving the defined priority actions, including receipt of over $\$ 2$ million in grant funds, implementation of multiple on-the-ground pilot projects, numerous educational events, and coordinated policy to support agriculture and improve water quality.
\end{abstract}

Keywords: collaborative, non-traditional partnerships, outcome-based solutions

Nitrogen $(\mathrm{N})$ and phosphorus $(\mathrm{P})$ contamination of water resources is a significant concern for the Chesapeake Bay and threatens the economic viability of farming communities within the Shenandoah Valley. Implementing sustainable and cost-effective solutions for nutrient management is critical for restoring water quality and sustaining agriculture. Nutrient reduction challenges in the Shenandoah Valley are significant because the excess nutrients in the region are largely in the form of manure and poultry litter, which

Eric Bendfeldt: Area Specialist, Community Viability, Virginia Cooperative Extension, 2322 Blue Stone Hills Drive, Suite 140, Harrisonburg, Virginia 22801 Email: ebendfel@vt.edu. Katharine Knowlton: Associate Professor, Virginia Tech, Department of Dairy Science, 3270 Litton-Reaves Hall (0315), Blacksburg, VA 24061 Email: knowlton@vt.edu. Tanya Denckla Cobb: Senior Associate, University of Virginia, Department of Urban and Environmental Planning, Institute for Environmental Negotiation, 104 Emmet Street, Charlottesville, VA 22903 Email: td6n@virginia.edu. Franklin Dukes: Director, University of Virginia, Department of Urban and Environmental Planning, Institute for Environmental Negotiation, Email: ed7k@virginia.edu. Kathy Holm: Coordinator, Shenandoah RC\&D Council, P.O. Box 60, Verona, VA 24482 Email: kathy.holm@va.usda.gov. Jactone Arogo Ogejo: Assistant Professor, Virginia Tech, Department of Biological Systems Engineering, 212 Seitz Hall, Blacksburg, VA 24061Email: arogo@vt.edu 
have traditionally been applied to cropland and are difficult and expensive to transport long distances. The Chesapeake Bay Commission's report, Cost-Effective Strategies for the Bay: 6 Smart Investments for Nutrient and Sediment Reduction, identified excess animal manure and poultry litter as an overarching problem for the Bay. Nutrient loads from manure and poultry litter to the Chesapeake Bay are estimated to be 20 percent of the total nutrient load; therefore, animal agriculture sectors like dairy, beef, and poultry are under considerable scrutiny and pressure to do their part to reduce these nutrient loads, while the effects and contributions of residents and municipalities are also being evaluated and addressed to improve the overall quality of the Bay (Chesapeake Bay Watershed Agricultural Summit, 2005).

Sustainability of animal agriculture in Virginia and the Shenandoah Valley is particularly important because of its history, economic impact and present prominence. In 2003 , Virginia ranked $5^{\text {th }}, 9^{\text {th }}$, and $31^{\text {st }}$ in the nation for commercial turkey, broiler, and egg production, respectively. The value of Virginia's turkey, broiler, and egg production was $\$ 692$ million. The six poultry processing companies in the Shenandoah Valley employ more than 7,000 people. Dairy farming generates $\$ 300$ million in farm receipts in Virginia. Presently, 40 percent of Virginia's 795 dairy farms are located in the Shenandoah Valley. The presence of these dairy farms and the extensive business infrastructure needed to support these farms have a positive economic impact on the local community and state economy because each dollar made on a dairy farm generates at least $\$ 2$ to $\$ 3$ off the farm (Chesapeake Bay Foundation, 2005; Cryan, 2004).

An important cultural linkage regarding sustaining agriculture, community viability, and environmental stewardship in the Shenandoah Valley are the efforts being made with dairy and poultry farmers within the Old Order Mennonite community of western Rockingham County. This community represents close to 25 percent of Virginia's dairy industry, owns and operates many of the area's poultry farms, and desires to maintain their culturally unique agriculture-based lifestyle, so working with them on nutrient management issues is particularly important.

The protection of water quality is critically important to Virginia and communities in the Shenandoah Valley, and the Chesapeake Bay watershed. Recreational and fishing activities in the Chesapeake Bay and its tributaries annually generate between $\$ 350$ million and $\$ 1.8$ billion dollars for Virginia and other Bay states. However, the Chesapeake Bay and many of its tributaries in Virginia and the Shenandoah Valley are listed as impaired water bodies by EPA because of excess nitrogen, phosphorus, and sediment loads.

Therefore, sustaining agriculture and protecting water quality are integrally linked to communities and the interests of various stakeholder groups in the Shenandoah Valley and the Chesapeake Bay watershed. This article addresses how diverse interest groups were mobilized around these issues in an innovative and cooperative grassroots effort, gathered for an outcome-based Waste Solutions Forum, and have continued to work collaboratively to identify and implement viable environmental solutions to support agriculture and water quality.

\section{LITERATURE REVIEW}

Formal and informal relationships and initiatives centered on watershed and ecosystem management, sustainable agriculture and communities, forest management, riparian restoration, grazing management, and capacity building are increasingly important (Carmin et al., 2004; Wondolleck \& Yaffe, 2000). Although collaboration is not a new concept, the urgency of contemporary problems and recognition of the potential benefits of collaboration are promoting acceptance and wider adoption as people look for sustainable solutions to complex problems. 
The impetus for the recent surge in collaboration among diverse interest groups includes shifts in public policy that encourage collaboration (Daniels, Senecah, \& Walker, 2006), failures of traditional public involvement to achieve desired outcomes (Booher \& Innes, 2004), renewed civic engagement (Leighninger, 2006), the multitude of geographic and jurisdictional boundaries involved in contemporary environmental and economic issues (Dukes, 1996), importance of a sense of place and community (Kemmis, 1990), and the need to find sustainable solutions through common ground (Cormick et al., 1996). Environmentalists and conservationists have to consider the social, economic, and environmental effects of policies, particularly as they become more interdependent in nature and practice. For instance, environmental and conservation groups are now realizing the loss of farmland to urban and suburban development poses potentially significant water quality concerns because of more impervious land surfaces, increased storm water runoff, and increased nutrient use when farmland is developed (Chesapeake Bay Foundation, 2005; Chesapeake Bay Commission, 2004). Similarly, the agricultural community is realizing farming practices have to be environmentally sound to be socially acceptable as well as commercially competitive. The collaborative approach, when used appropriately, allows people with varied interests to discover a set of shared values and determine ways of meeting one another's needs (Wondolleck \& Yaffe, 2000; Dukes \& Firehock, 2001).

Interest in sustainability and long-term durable solutions has encouraged the change from one-time negotiations and court battles to more collaboration and community-based problem solving among diverse groups (Emerson et al., 2003). Unique public-private partnerships have been formed that mobilize people and increase their capacities for the understanding and trust needed for effective action and change (Leach \& Sabatier, 2005). Similarly, the goals of a healthy economy and a healthy environment are not mutually exclusive, but are inextricably linked so that collaboration and collective action is requisite for effective problem solving.

Bradshaw and Pigg (2003) outlined a model for catalytic community development built on collaboration as a key component. With this model, the emphasis is on identifying and mobilizing local expertise, leveraging local resources, and creating networks and partnerships for community-based solutions. Other characteristics of catalytic community development include capacity-building, empowerment, expanded locus of activity, open access to information, and coalitions that are flexible and loosely aligned to maintain independence while fostering a collaborative structure to encourage seamless service. Bradshaw and Pigg (2003) emphasize that communities with robust associational and organizational structures nurture civic engagement and are best able to meet the social and economic needs of the community.

Proponents for collaboration cite the benefits as encouraging innovative solutions, promoting problem solving and effective results, building community sustainability, and expanding the conservation and civic toolbox (Booher \& Innes, 2004; Dukes, 2004). Critics of some forms of collaboration point to co-optation as a real possibility; local control that might compromise regional and national resources and interests; the survival and persistence of lowest common denominator solutions; issues of complacency, representation, irreconcilable values, precedent, and authority that can have lasting negative effects if parties are not aware of the issues and possibilities (Kenney, 2000; Coggins, 1998). Hence, care must be taken to use collaborative processes only in appropriate circumstances and with proper support (Booher \& Innes, 2004; Leach \& Pelkey, 2001).

\section{METHODOLOGY}

Animal agriculture is particularly intense and important in the Shenandoah Valley because of its history, economic impact, present prominence, and ecological role in 
preserving working landscapes and open space. However, the dairy and poultry farms in the Shenandoah Valley are within the Chesapeake Bay watershed; and the Bay and many of its tributaries are listed as impaired water bodies by EPA because of excess nitrogen, phosphorus, and sediment loads. Animal agriculture has been identified as contributing to this water quality impairment, along with urban and residential sources.

An important cultural aspect that contributes to the increased urgency to proactively address the nutrient challenges facing animal agriculture and the Bay are the efforts being made with dairy and poultry farmers within the Old Order Mennonite community of western Rockingham County. The Old Order Mennonite community and lifestyle is pre-dominantly agriculture-based. The community's simple or plain ethos is typified by non-conformity, non-resistance, horse-drawn buggies, and a strong sense of faith and community. Therefore, sustaining agriculture and protecting water quality are integrally linked to communities and the interests of various stakeholder groups in the Shenandoah Valley and the Chesapeake Bay watershed.

A cooperative grassroots effort was initiated in 2004. The Waste Solutions Forum was established to build a consensus among the agricultural and environment conservation communities and other interest groups on long-term collaboration and partnerships towards a common vision of clean water and thriving agricultural communities within the Shenandoah Valley and Chesapeake Bay Watershed.

The initial discussion and effort was initiated by the Virginia State Dairymen's Association and the Chesapeake Bay Foundation. They organized several exchange trips for Farmers to the Bay and Watermen to the Valley as an ongoing educational program. Through these exchanges, participants realized the benefit and value of a process and partnership that promotes problem-solving and focuses on individual interests as well as shared concerns. The educational exchanges between farmers, watermen, and the two organizations have helped allay fears and misgivings, overcome differences, and find common ground to support agriculture and protect water quality.

Within this context, a diverse group of people with backgrounds in agriculture, environmental science, research, education, business, legislation, and policy met in Roanoke, Virginia on April 28 -29, 2005, for the Waste Solutions Forum to find common ground, explore innovative solutions, and develop a concrete strategy to address the nutrient challenges of animal agriculture in the Shenandoah Valley. To design this event, a group of nearly twenty people representing different interests formed a planning committee. Because of the longstanding differences and common, very public conflicts between the interests represented at this planning table - environmental, agricultural, academic, state government - members of this planning group understood that their discussions were critical for the event's success; if they could not agree on the goals for the Forum or how the Forum should be conducted, it would never occur. All were drawn to participate in the planning by two key factors: the increasingly urgent need to find new ways of managing excess animal manure for the Shenandoah Valley's intensive agricultural production and the knowledge that long-term solutions would require the cooperation, if not collective action, of all the key interests.

Over the course of nine months, with the assistance of an independent facilitator skilled in process design as well as group facilitation, this planning committee worked to sharpen its focus and methodology for the Forum. Through this planning period, members of the committee consulted their organizations, sharing the committee's emerging ideas for how the Forum would work, and bringing their organization's feedback to the planning committee. This, too, was a critical aspect for the eventual Forum success, as the planning effort thus effectively obtained broader buy-in to the Forum goals and created anticipation, as well as some anxiety, among diverse stakeholders about what the Forum might yield. The planning committee eventually came to agree that the Forum would have three key 
goals: 1) Educate all participants about the issues to ensure that all had the same essential basic knowledge for making decisions; 2) Provide participants with significant time to have open discussion about the issues, with facilitators ensuring that discussion remained productive and focused on the future and possible solutions, not degrading into rehashing the past and finger-pointing; and 3) Invite participants to develop ideas and recommendations that were specific, concrete, and could be implemented in the next five years. To keep participants focused, the discussion groups would be organized into four topic areas: education, research, pilot projects, and policy. In short, the planning committee wanted the Forum to avoid the pitfalls of other gatherings that produced dust-gathering reports and, instead, create a strategic plan with very specific actions that could be turned around and implemented immediately.

The Waste Solutions Forum was envisioned as both an event and an ongoing process. The two-day Forum would develop a strategic plan, and at the end of this event a new Waste Solutions steering committee would be formed to guide implementation of the plan.

\section{RESULTS}

As an innovative and cooperative approach to support agriculture and protect water quality in the Shenandoah Valley, the invitation-only Forum gathered 80 key stakeholders who were selected to represent diverse interests - the agricultural commmunity, environmental and conservation groups, universities, and representatives from local, state, and federal government. Working collaboratively to find viable and durable solutions for nutrient management, participants willingly set aside historical differences and individual interests to work toward a shared vision of clean water and a thriving agricultural community in the Shenandoah Valley. A significant part of this willingness was engendered by the careful outreach efforts of the planning committee to keep all organizations informed during the planning phase, and its efforts to educate all participants with issue briefs provided in advance as well as presentations at the Forum.

Differences certainly emerged during the group discussions, particularly the discussion on policy; furthermore, far more ideas emerged from discussions than could be implemented. But common ground was also not hard to find. Participants were asked to identify their individual priorities based on which of the many proposed actions would be most do-able in the next three years, which would make the greatest different for the least investment, and which needed to happen first before other things could be accomplished. Participants were assured that all ideas would be recorded in the strategic plan, with no ideas lost or dropped, which provided a kind of psychological space for people to focus less on ownership of a particular idea and more on what would improve Valley agriculture and nutrient management.

The participants all had vested interest in the nutrient challenges and were keenly interested in coming away from the Forum with specific actions and plans. The shared interests included helping farmers to find economic and cost-effective solutions to stay commercially competitive, to improve and protect state waters through the stewardship of a viable farm community, to enhance compliance with water quality standards and current environmental regulations, to protect the rural agricultural heritage and the cultural uniqueness of farm communities, to develop and implement effective and compliant nutrient reduction technologies, and to seek cost-effective non-polluting renewable energy as alternatives to foreign oil.

Over the two days of the Forum, participants narrowed their priority actions to fit within four topic areas: (1) Improve the nutrient efficiency of feeds to reduce $N$ and $P$ in manure and poultry litter without compromising animal and bird health or productivity; (2) Improve demand and markets for manure and poultry litter-based products; (3) Develop and 
implement alternative methods for processing manure and poultry litter and end uses for these organic resources to include, but not be limited to, nutrient reduction and renewable energy technologies and a regional farmer-based cooperative to work toward these goals; and (4) Encourage the development of state and federal policies to ensure funding and achieve the overall goals of the Forum (Denckla Cobb, 2005).

Not all aspects of Forum went smoothly for all participants. Some participants were clearly disappointed that their favorite ideas did not receive sufficient support to become a priority in the strategic plan. Some were also frustrated at the pressure of the time-frame for the group discussions, expressing desire for more time to think about and discuss all the ideas on the table. In addition, the Forum process was complex and, before prioritization, some participants expressed a sense that it felt chaotic - too many ideas on the wall, too hard to visually read them all, too hard to sort through them, too hard to make choices. At the same time, many participants expressed satisfaction in the process itself, especially the fact that all ideas would be heard and fairly considered. Also, some participants expressed relief that the process had a limited timeframe, forcing people to make choices and come to specific conclusions.

Given the high stakes for all participants and the high-pressure nature of the process, the Forum had at least three immediate concrete measures of success. No participant expressed an inability to support the outcomes, nor disenfranchisement or withdrawal of their organization from the Forum process, which would have represented a significant blow to the Forum's legitimacy and credibility. Conversely, the Forum strategic plan received broad support from all participants, smoothing the way for its implementation. In addition, reflecting the Forum's success in engendering participant buy-in and enthusiasm, a number of participants volunteered at the end of the Forum to work on the new steering committee to guide implementation of the strategic plan. These measures of success, however, were not the ultimate test of the Forum's success. For the Forum to be successful in the planners' eyes, measurable results would need to be seen within several years. After the Forum in 2005 , the voluntary steering committee continued to meet regularly as a rolling coalition to advance the goals and priorities recommended. Significant accomplishments of the past two years include movement forward on pilot projects, research and education:

Research/ Pilot Project: initiating a $\$ 1.2$ million precision phosphorus feeding pilot project for dairies, funded by USDA Natural Resources Conservation Service (NRCS) and Virginia's Deprtment of Conservation and Recreation (DCR);

\& Pilot Project: implementing a $\$ 1$ million grant project to pilot innovative and cooperative approaches to utilize and export the Shenandoah Valley's organic resources and reduce nutrients to the Chesapeake Bay by converting poultry litter into a bio-oil, slow-release fertilizer, syngas, and value-added product; isolating and precipitating phosphorus out of liquid dairy manure for more effective application and transportation of dairy manure; hiring an "on-the-ground" market maker to facilitate movement of poultry litter and manure-based products to nutrient deficient areas and out of the watershed; demonstrating the effectiveness of manure-based compost as a soil amendment on reclaimed highway construction sites, funded by the National Fish and Wildlife Foundation and Farm Pilot Project Coordination, Inc.;

- Pilot Project: forming a subcommittee, the Valley Organic Resources Cooperative, to work on a variety of cooperative initiatives throughout the Valley such as a community-based manure processing and methane recovery system within the Old Order Mennonite community and a local poultry processing cooperative to encourage nutrient reduction on farms with limited acreage and renewable energy co-generation; 
8. Pilot Project: collaborating with Protected Harvest, the Environmental Defense's Center for Conservation Incentives, and Virginia Tech to pilot a project to encourage and reward dairy farmers in the marketplace through an eco-friendly label for implementing best management practices and water quality improvement measures on their farms;

Policy: proposing an innovative manure and poultry litter management subprogram within the 2007 Farm Bill;

T. Policy: assessing incentives for efficient poultry litter management;

- Education: funding a bio-energy fact-finding trip by academics, industry representatives, and Valley farmers to Europe to explore existing pyrolysis technology; and

: Education: implementing numerous nutrient management, water quality, and renewable energy based educational and extension programs.

Through both the lengthy planning process, the two-day Forum in 2005, and the subsequent two years of steering committee efforts, the Forum has succeeded in building long-term collaboration between traditional and non-traditional partners to address the nutrient challenge associated with animal agriculture and implement environmental solutions in the Shenandoah Valley. The steering committee continues to be a safe place where partners can air and resolve differences, while working on shared goals for implementing the Forum strategic plan.

The collaborative approach and the momentum of the WSF will continue through completing existing projects. Specifically, the steering committee envisions implementing the following aspects of the WSF strategic plan:

Education (Planning and Partner Development): holding a follow-up Waste Solutions Forum II to review accomplishments to date, re-evaluate the solutions strategy, and solicit new ideas for priority actions;

Pilot Project: coordinate and pilot an adaptive stream fencing program to augment and complement existing livestock exclusion programs offered by federal and state conservation agencies;

f. Policy: coordinate with Virginia's Natural Resource, Agriculture, and Forestry Secretariats to develop and seek the Governor's issuance of an official Executive Order seeking greater use of Virginia manure and litter as fertilizer on Virginia lands;

8 Education: host a symposium to bring national experts together in the Valley to discuss innovative means to address excess nutrients and produce energy and value-added products;

Education: hold educational field days that market new technologies piloted under grants and other novel approaches to producers and policy-makers; and

Policy/Pilot projects: develop and advocate for incentive-based programs to facilitate efficient poultry litter management.

\section{SUMMARY AND CONCLUSION}

The contamination of water resources and threat to the economic viability of farming communities make action and collaboration imperative. The Waste Solutions Forum and its steering committee's on-going efforts have proven successful in bringing together a diverse group of people with various vested interests but shared concerns about the health of the Chesapeake Bay and the long-term viability of agriculture in the Shenandoah Valley. Maintaining the group's cohesion will be an on-going challenge as the group faces different issues and concerns related to agriculture and the environment. However, together, the 
group has taken positive steps to improve water quality and sustain agriculture in the Shenandoah Valley of Virginia by implementing a strategic plan aimed at research, pilot projects, educational programs, and policies necessary for practical and durable solutions.

\section{REFERENCES}

Booher, D. E. \& Innes, J. E. (2004). Reframing public participation: Strategies for the 21 st century. Planning Theory \& Practice 5(4), 419-36.

Bradshaw, T.K. \& Pigg, K.E. (2003). Catalytic community development: A theory of practice for changing rural society. In D.L. Brown \& L.E. Swanson (Eds.), Challenges for rural America in the twenty-first century (p. 385 - 396). University Park, Pennsylvania: Pennsylvania State University Press.

Carmin, J., Koontz, T. M., Mosely, C., Smith Korfmacher, K., Steelman, T.A. \&. Thomas, C. W. (2005). Collaborative environmental management: What roles for government? Washington, D.C.: Resources for the Future.

Chesapeake Bay Commission. (2004, December). Cost-effective strategies for the Bay: Six smart investments for nutrient and sediment reduction. Annapolis, Maryland.

Chesapeake Bay Foundation. (2005, September). Vital signs: Assessing the state of Chesapeake agriculture in 2005. Annapolis, Maryland.

Chesapeake Bay Watershed Agricultural Summit. (2005, January). Finding solutions to excess animal manure and poultry litter. Proceedings of the Chesapeake Bay Watershed Agricultural Summit. Sponsored by the Mid Atlantic Regional Water Quality Program of the Land Grant Universities and the U.S. Environmental Protection Agency Chesapeake Bay Program Office.

Coggins, G. C. (1998). Of californicators, quislings, and crazies: some perils of devolved collaboration. Chronicle of Community 2(2).

Cormick, G., Dale, N., Emond, P., Sigurdson, G. \& Stuart, B. (1996). Building consensus for a sustainable future: Putting principles into practice. Ottawa: National Round Table on the Environment and the Economy.

Cryan, R. (2004, May). The economic impact of the dairy industry. U.S. Dairy Markets \& Outlook. 10:1. Dairy Management, Inc. Rosemont, Illinois.

Daniels, S. E., Senecah, S.L. \& Walker, G.B. (2006). From the forest to the river: Citizens' views of stakeholder engagement. Human Ecology Review 13(2), 193-202.

Denckla Cobb, T. (2005). The waste solutions forum: Final report and solutions strategy. Virginia Polytechnic Institute and State University: Blacksburg, Virginia.

Dukes, E. F. (1996). Resolving public conflict: Transforming community and governance. Manchester: Manchester University Press.

Dukes, E.F. (1996). What we know about environmental conflict resolution: An analysis based on research. Conflict Resolution Quarterly 22(1-2), 191-220.

Dukes, E. F. \& Firehock, K. (2001). Collaboration: A guide for environmental advocates. Charlottesville, VA: Institute for Environmental Negotiation, The Wilderness Society, National Audubon Society.

Emerson, K., Nabatchi T., O’Leary, R., \& Stephens, J. (2003). The challenges of environmental conflict resolution. In R. O'Leary \& L.B. Bingham (Eds.), The promise and performance of environmental conflict resolution (3-26). Washington, D.C.: Resources for the Future.

Kemmis, D. (1990). Community and the politics of place. Norman, Oklahoma: University of Oklahoma Press.

Kenney, D. S. (2000). Arguing about consensus: Examining the case against western watershed initiatives and other collaborative groups in natural resource management. Boulder: Natural Resources Law Center at the University of Colorado School of Law.

Leach, W.D. \& Pelkey, N.W. (2001). Making watershed partnerships work: A review of the empirical literature. Journal of Water Resources Planning and Management 127(6), 378-85.

Leach, W. D. \& Sabatier, P.A. (2005). To trust an adversary: Integrating rational and psychological models of collaborative policymaking. American Political Science Review 99(4), 491-503.

Leighninger, M. (2006). The next form of democracy: How expert rule is giving way to shared 
governance-and why politics will never be the same. Nashville, Tennessee: Vanderbilt University Press.

Wondolleck, J.M. \& Yaffe, S. L. (2000). Making collaboration work: Lessons from innovation in natural resource management. Washington, DC: Island Press. 
Copyright of Community Development is the property of Community Development Society and its content may not be copied or emailed to multiple sites or posted to a listserv without the copyright holder's express written permission. However, users may print, download, or email articles for individual use. 